\title{
We're still failing to deliver open access and solve the serials crisis: to succeed we need a digital transformation of scholarly communication using internet-era principles.
}

\author{
Toby Green \\ OECD Publishing, \\ Organisation for Economic Cooperation and Development (OECD), \\ 2 rue André Pascal, Paris, 75775 Cedex 16, France \\ toby.green@oecd.org@tobyabgreen https://orcid.org/0000-0002-9601-9130
}

Key points:

- We're still failing to deliver open access (OA): around a fifth of new articles will be born free in 2018, roughly the same as in 2017.

- Librarians, funders and negotiators are getting tougher with publishers but offsetting, 'Publish and Read', deals based on APCs won't deliver OA for all or solve the serials crisis.

- The authors of Budapest, Bethesda and Berlin OA declarations foresaw three changes with the coming of the internet. Flipping to a barrier to publish (APCs) from a barrier to read (subscriptions) wasn't one of them.

- By itself, OA won't reduce costs to solve the serials crisis: a digital transformation of scholarly communications based on internet-era principles is needed.

- Following the internet-era principle of 'fail-fast', what if papers are first posted as preprints and only if they succeed in gaining attention will editors invite submission to their journal?

- In clinging onto traditional journals to advance the careers of the few (authors), OA is delayed for the many (readers): rebuilding the reputation economy to accept preprints could be the catalyst to deliver OA, solve the serials crisis and drive out predatory journals.

\section{Introduction}

A year ago, I concluded that we had failed in our quest to make scholarship open access (OA): the race had been won by pirates like SciHub (Green, 2017a). Twelve months on, how do things look?

\section{Unclothed, still}

This year it is likely that the proportion of articles born-OA, globally, will not be much above the $20 \%$ born-OA in 2017 and half the backlist will remain pay-walled (Alperin, 2018; Bosman \& Kramer, 2018; Martín-Martín et al, 2018a; Piwowar et al, 2018). In 2010, the number of newly published pay-walled articles was around 0.94 million. In 2016, this number had increased $36 \%$ to 1.28 million (figure 1) at a time when the OA movement was not only very active but launching new OA journals at pace (Liu \& $\mathrm{Li}$, 2017). Of 2016's articles, $25 \%$ are OA, a modest improvement on the $20 \%$ of 2010's articles (Bosman \& Kramer, 2018). Even in the UK, a country where, post-Finch, there has been concerted support for Gold OA, only $37 \%$ of articles were born free in 2016 (Universities UK, 2017). So, we're still failing. 
Green, T: We're still failing to deliver $O A$ and solve the serials crisis: to succeed we need a digital transformation of scholarly communication using internet-era principles.

However, while the numbers that matter may not have improved over the past twelve months, the environment has changed.

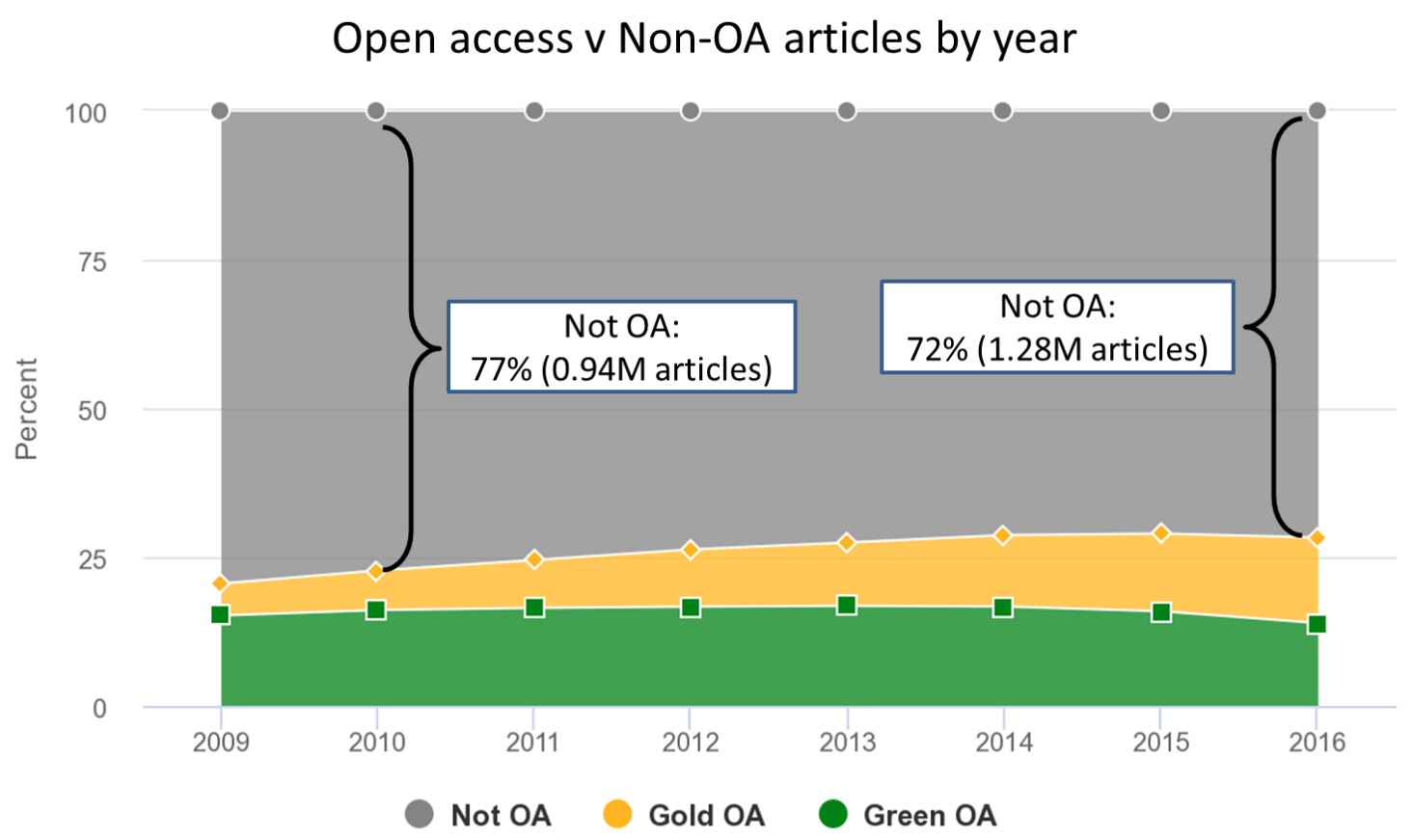

Figure 1: OA articles v Non-OA Articles. Source: European Commission Open Science Monitor calculations using Scopus database https://ec.europa.eu/info/open-science/open-science-monitor/trends-open-access-publications_en

\section{Librarians show some muscle}

At the beginning of the decade, there were rumblings that librarians would call publishers' bluff over renewals to the point that investment analysts were issuing 'sell' recommendations for the big commercial publishers. It proved to be a false dawn, publishers managed to deliver better value (Anderson, K., 2013) so big deals were renewed and publishers' profit margins continued at around 35\% (Buranyi, 2017).

Over the past year, this has changed, especially in Europe (Schonfeld, 2018a). The Dutch want to pay for output, nothing more ${ }^{1}$ and Norway's funders are taking the same position (Else, 2018). Finland wants to limit a yearly price increase to $2.25 \%$ and get a $50 \%$ discount on OA article publication charges (APCs) ${ }^{2}$. Negotiators, such as in Austria, France, Germany and Switzerland, are working with publishers on 'Publish and Read' deals (also known as offsetting) whereby a publisher agrees to publish articles on an OA basis (Publish) and provide access to pay-walled articles (Read) under a single, bundled, deal: in Germany's case, for no overall price increase ${ }^{3}$. University of California would like to shift to paying for APCs rather

\footnotetext{
${ }^{1}$ https://www.scienceguide.nl/2018/01/we-are-prepared-for-no-deal/

2 also referred to as Article Processing Charges or Article Publishing Charges

${ }^{3}$ https://www.hrk.de/press-releases/press-release/melding/european-high-level-summit-meeting-on-open-access-negotiations-4364
} 
Green, T: We're still failing to deliver OA and solve the serials crisis: to succeed we need a digital transformation of scholarly communication using internet-era principles.

than subscriptions (Schonfeld, 2018b). Some negotiations have failed, notably the Projekt Deal (Germany) and Bibsam Consortium (Sweden) talks with Elsevier which led to loss of access to new pay-walled articles in both countries (Smith, 2018; Kämper, 2018; Fowler \& Meijer, 2018). Other negotiations, such as between RSC and VSNU, have stalled (Poynder, 2018a). Most recently, Europe's Plan S throws down a significant gauntlet to subscription journals (Else, 2018).

This newly assertive stance by librarians and funders is bolstered by new principles for negotiation such as 'no OA, no price increase', 'no deals without OA offsets', 'access should be sustainable' and recommendations for cost transparency (van Otegem et al, 2018; University of California, 2018; ScienceEurope, 2018).

At first glance, the growth in number of cancellations seems impressive (Figure 2) but when measured against all consortia, they are still marginal (Figure 3). Some speculate that this 'can't pay, won't pay' stance spooked investors considering Springer's IPO in May (Worlock, 2018).

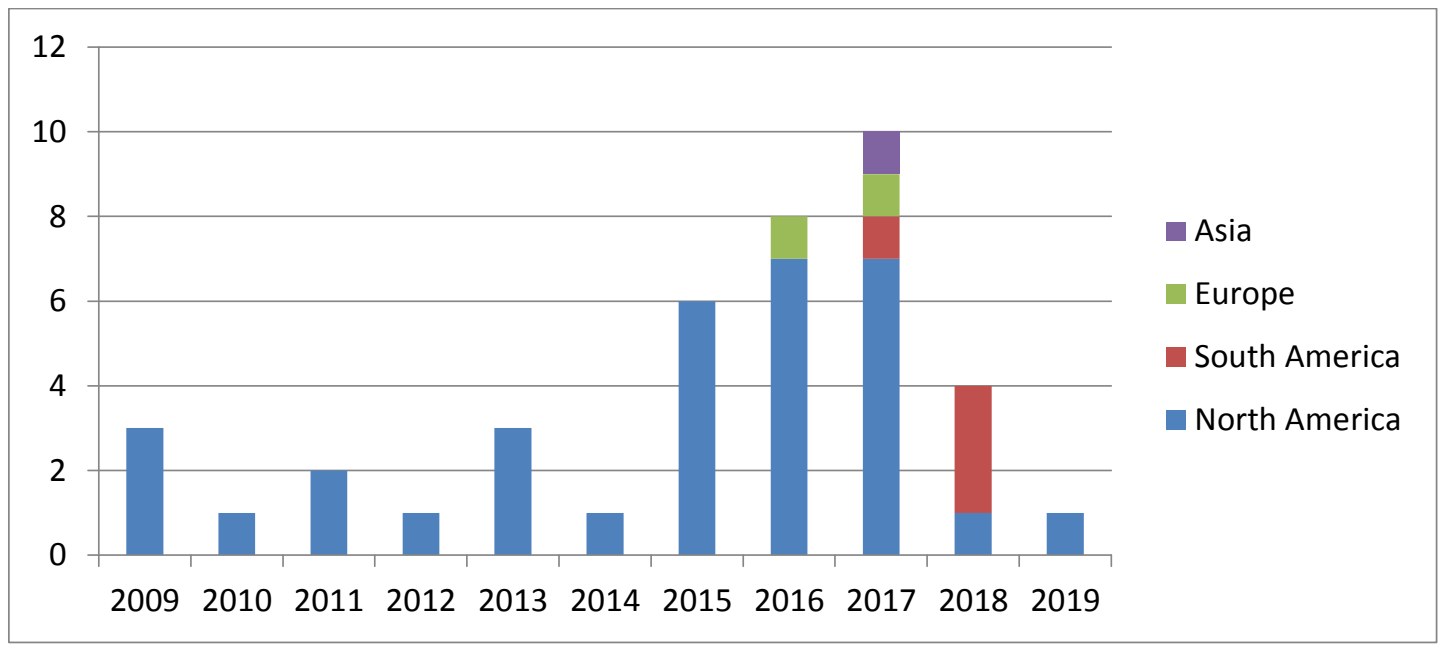

Figure 2: Chart showing the number of big deal cancellations per year. Source: author's calculations based on Anderson, R., 2018a and SPARC ${ }^{4}$.

\footnotetext{
${ }^{4}$ https://sparcopen.org/our-work/big-deal-cancellation-tracking/
} 


\section{PREPRINT}

Green, $\mathrm{T}$ : We're still failing to deliver $\mathrm{OA}$ and solve the serials crisis: to succeed we need a digital transformation of scholarly communication using internet-era principles.

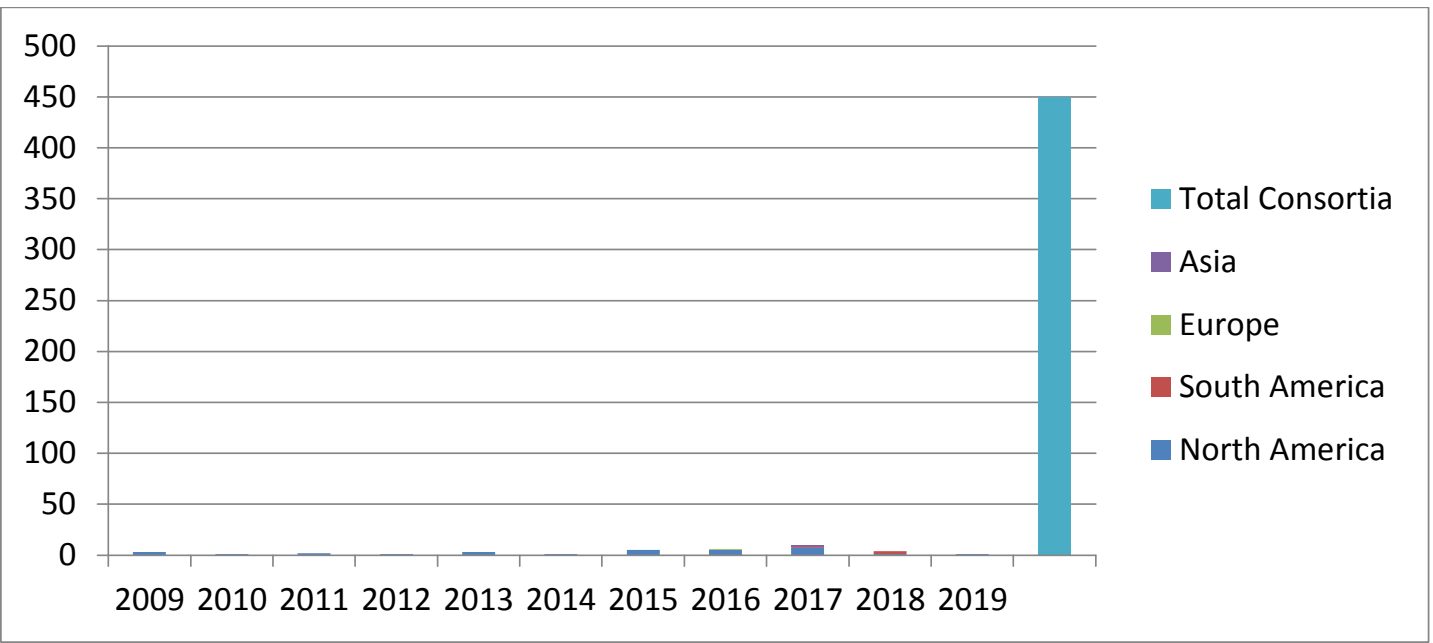

Figure 3: Chart showing the number of big deal cancellations per year compared to the total number of consortia as recorded by Ringgold's Consortia Directory. Source: author's calculations based on Anderson, R., 2018b and SPARC.

\section{Toil and trouble in the shadow of the 'Scottish service'}

Why now? Perhaps librarians have been emboldened by the knowledge that subscription content only makes up half of what researchers actually access via legal channels (Piwowar et al, 2018) and otherwise their needs could be met satisfactorily by inter-library loans, preprints, plug-ins and tools that lower the effort of finding free versions of pay-walled content, and social channels like ResearchGate which hosts nearly three-quarters of a million freely accessible documents (Anderson, K. 2018a; Esposito, 2018a; National Library of Sweden, 2018; Martín-Martín et al, 2018a). Unspoken, SciHub, which being unmentionable perhaps we should refer to as the 'Scottish service', continues to harvest $85 \%$ of all paywalled articles rising to $90 \%$ if they have been cited (Himmelstein et al, 2018).

Early reports suggest that researchers in Germany and Sweden are doing just fine without an Elsevier deal (Times Higher Education, 2018), but since they still have access to anything published before the old deals expired it may be some time before the full effect of no-deal becomes apparent (Smith, 2018; Kämper, 2018). But are negotiators right to be pushing for APC deals?

\section{Will flipping flop?}

If there is enough money in the system to fund traditional, pay-wall, publishing logically, some argue, it should be possible to 'flip' the business model to fund OA publishing (Schimmer et al, 2015). Flipping could occur through a combination of scholcomm institutions creating and financing journals themselves and/or funding publisher-run journals via APCs or otherwise.

\footnotetext{
${ }^{5}$ According to theatrical superstitition, speaking the name of Shakespeare's play Macbeth invites disaster, so thespians refer to it as the Scottish Play and the lead character as the Scottish King. Perhaps invoking the name of SciHub will invite disaster on our house too! https://en.wikipedia.org/wiki/The_Scottish_Play .
} 
Green, T: We're still failing to deliver $\mathrm{OA}$ and solve the serials crisis: to succeed we need a digital transformation of scholarly communication using internet-era principles.

Whilst the Directory of OA Journals (DOAJ) has 8,730 journals tagged as not charging APCs compared to 3,152 charging $\mathrm{APCs}^{6}$, the ratio of non-APC-funded OA articles to APC-funded OA articles is probably closer to 50:50 (Suber, 2017). That APCs might be the more scalable funding model for Gold OA articles ${ }^{7}$ is supported by the news that the market for Gold APCs showed a double-digit increase in 2016-2017 although this growth was partly fuelled by APC prices rising faster than inflation -, the Read and Publish deals, and Europe's Plan S (Simba Information, 2018; Fowler and Meijer, 2018; Else, 2018). Let's take a look at some of the issues around APCs.

\section{APCs: playwalls, pressures and predators}

APCs typically cost \pm US $\$ 600$ for fully OA journals and \pm US $\$ 2,000$ for most hybrid journals (Pinfield \& Johnson, 2018) which is a barrier to get published, a 'playwall', if you will, instead of a pay-wall to read. This is a price discrimination 'flip'. Whereas before those without funding couldn't access journals, now those without funding won't get published opening a new front in the North/South knowledge divide (Poynder, 2018b; Raju, 2018) and a prohibitive disadvantage to those who are not supported by wealthy institutions or funders (Peterson, et al, 2018). A market for APCs might incentivise publishers to lower quality thresholds in order to win more business (Horton, 2018).

APC prices at these levels create a market opportunity for new entrants offering publication fees as low as US\$200 (Shen \& Björk, 2015). While some authors, including from elite institutions, have felt conned by the so-called 'predatory' nature of these new entrants, others consider these journals a godsend because they do not discriminate against non-Western researchers, offer rapid turnaround times, advance careers and build reputation (Poynder, 2018b; Beall, 2017; Kurt, 2018; Pyne, 2017; Oberhaus, 2018). In India and China, the evaluation systems used for hiring and promotion can reward academics for the quantity of publications they publish, not the quality, so no wonder there is a ready demand for these low-priced journals. However, these titles, which number in the thousands and publish tens of thousands of articles annually, are gaining the attention of regulators and the mainstream media concerned that scholarship is being undermined by fake science (Priyadarshini, 2018; The Economist, 2018; Anderson, K. 2018b; Anderson, R., 2018b; Hern \& Duncan, 2018).

Some are not so sure about APCs. Three large consortia in the Spanish-speaking world have said that APCs distort the market and is financially impossible for them (Ibero-American and Caribbean Consortium, 2017). In the USA, the number of new APC funds being created has declined sharply since 2012 and some are sunsetting theirs citing budget constraints and that APCs had not slowed rising journal subscription costs (Johnson et al, 2018; Neuerburg, 2018).

There are worries that replacing big subscription deals with big APC deals simply flips inequity in accessing content with inequity in publishing content while the same 'locked in' dollars flow to the same dominant platforms and publishers and stifle price competition (Hinchliffe, 2018; Schonfeld, 2018b).

\footnotetext{
${ }^{6}$ https://doaj.org/

7 For the sake of convenience, I'm using Piwowar's definition of Gold OA: articles published in journals indexed by DOAJ. Journals indexed by DOAJ have a variety of funding models of which APCs is one.
} 
Green, $\mathrm{T}$ : We're still failing to deliver $\mathrm{OA}$ and solve the serials crisis: to succeed we need a digital transformation of scholarly communication using internet-era principles.

Whilst Stockholm University has said it will use the money it has saved from the cancellation of the Bibsam agreement to meet the cost of APCs (Stockholm University, 2018), flipping could be undermined by publicly-funded institutions' procurement rules which are usually designed around market principles, open competition and best value for money. High APCs could trigger rules that require multiple bids or sole provider justification, adding administrative burden to the process (Caldeira, 2018). Paying for APCs when some fully OA journals charge nothing might be unlawful in some jurisdictions and using public funds to contribute towards crowd funded, shared, open platforms fall foul of rules that require a direct benefit that would not otherwise be available (Eve, 2018).

On the other hand, flipping will probably get a boost if cOAlition $\mathrm{S}$, launched by the European Commission and 11 national research funding organisations, succeeds in bringing Plan $\mathrm{S}$ to fruition. Plan S, has one target:

"By 2020 scientific publications that result from research funded by public grants provided by participating national and European research councils and funding bodies, must be published in compliant OA Journals or on compliant OA Platforms."

and ten principles including that APCs will be covered by funders or institutions, not individual researchers ${ }^{8}$. While some praise this initiative, it could be seen as a coalition of patrons using their power to limit author choice (Anderson, K., 2018c).

Leading research institutions publish thousands of papers annually, teaching-focussed universities might publish a few score and corporate or government entities might publish a handful. Consequently, in a flipped world, the lion's share of the cost of publishing will swing to large research institutions and away from those who publish less (worth noting that $\pm 25 \%$ of subscription revenues come from industry (Hersh, 2017) leading to a fundamental question: will the former be able to foot their APC bill and will the latter free-ride (Esposito, 2018b)? Germany, worried that its cost of publishing could increase hasn't signed up to Plan S (Else, 2018).

This quick survey through the APC landscape suggests that switching to this method of funding publication costs isn't going to be smooth or scale fast.

\section{I'm an author, get me out of here}

Researchers find themselves with conflicting pressures. On the one hand, their funder and employer are probably mandating OA in one way or another and pester them to post on anonymous institutional repositories (Poynder, 2018c) and can threaten sanctions if they fail to comply (Else, 2018). On the other hand, their career prospects are dependent on promotion committees still in thrall to a reputation economy largely built on traditional journals (Heinemann et al, 2018). In the middle there is the notion of academic freedom in the publication of results and arguments as to whether their research results are a private good to be shared with fellow practitioners or a public good for everyone's benefit (Martin, 2018).

\footnotetext{
${ }^{8}$ https://www.scienceeurope.org/coalition-s/
} 
Green, T: We're still failing to deliver $\mathrm{OA}$ and solve the serials crisis: to succeed we need a digital transformation of scholarly communication using internet-era principles.

Even if authors try to comply with mandates, they are confronted by a bewilderment of different publisher practices, processes and terms and conditions compounded by tedious APC-related administrative tasks (van der Graaf, 2017). It is clearly impossible for a university's support staff to hold every author's hand through the process. Worse, each institution is setting up its own workflow and these necessarily lack an economy of scale (Pinhasi et al, 2018; Kingsley, 2018a).

Despite the increasing support ${ }^{9}$ for improvement in how scientific research outputs are evaluated by funding agencies, employers and others (DORA, 2012), only 5\% of career-dependent review, promotion and tenure protocols in North America mention OA and of those that do some only point to the potential risks of OA journals (Alperin et al, 2018). Canada's model policy on scientific integrity only asks authors to 'explore' the possibility of OA publishing ${ }^{10}$. Most French researchers' journal choice is shaped by the desire to further reputation, career and professional impact (Boukacem-Zegmouri et al, 2018). If review, tenure and promotion committees remain sceptical about publishing outside the traditional 'reputation economy' titles, why risk publishing in OA journals?

\section{What's not to like about hybrids?}

If the traditional 'reputation economy' journals are so central to career progression and grant-winning but funders and employers mandate OA, then publishing in traditional journals that offer OA under the hybrid model seems the obvious, win-win, solution. Better still, OA articles in hybrid journals are downloaded four times more than their closed access peers and are significantly more likely to be cited and mentioned in policy documents: hybrid OA articles published 2009-2015 had a citation impact 30\% higher than the world average and are comparatively more likely to be cited than articles in fully OA journals. (SpringerNature, 2018; Piwowar et al, 2018). What's not to like?

For some, a lot. Hybrid OA is considered to be 'the worst of both worlds' (Matthias, 2018), expensive, poor value for money (Boyes and Kingsley, 2016), and unacceptable to many APC budget holders, over half of whom limit spending to fully OA journals only (Kingsley and Boyes, 2016; Stockholm University, 2018). Europe's Plan S specifically rules out hybrids, questioning its future in Europe (Johnson, 2018), but with $\pm 45 \%$ of journals being hybrid today, many the best in their field, academics may question the future of Plan S (Else, 2018; Kammerlin, 2018).

\section{The iron law of musical chairs}

In a flipped world, if authors are in poorly-funded fields, institutions or countries they could easily find themselves without the means to publish in the journal of their choice (Raju, 2018). They could rely on Diamond/Platinum titles ${ }^{11}$ but these will have their capacity limited by the ability of institutions and/or

\footnotetext{
${ }^{9}$ at the time of writing ( $30^{\text {th }}$ August 2018), 512 institutions and 12,582 individuals had signed the San Francisco Declaration on Research Assessment (DORA) https://sfdora.org/signers/

${ }^{10} \mathrm{http}: / /$ science.gc.ca/eic/site/063.nsf/eng/h_97643.html Paragraph 7.5.6 5th bullet point

${ }_{11} \mathrm{OA}$ journals which do not charge APCs are classed as Diamond or Platinum. These titles are financially supported by donors, institutions or funders and often with the support of volunteers.
} 
Green, T: We're still failing to deliver OA and solve the serials crisis: to succeed we need a digital transformation of scholarly communication using internet-era principles.

volunteers to bear the cost. Unless covered by deals like Publish and Read, authors are going to have to convince their own institution or their research funder to foot APC bills which may be a challenge even if they are at a wealthy institution.

For example, Hong Kong University has calculated that if all 2,500 of their articles published in 2017 in hybrid journals were APC-funded, it would have cost USD7.1 million on top of the USD1.5 million they already spend on APCs in fully OA journals. This USD7.1 million is $150 \%$ more than they spend on the top 5 publisher subscription journals and would still leave 1,500 of their articles closed access. It's worth noting that the number of articles being published by HKU has grown $75 \%$ over the past ten years to nearly 5,000 in 2017 (at a potential APC cost of around USD12 million) - how many institutions are prepared to increase funding for APCs at this rate? (Chan, 2018).

Unless the combined capacity of Diamond/Platinum journals and APC-funds grows at a pace equal to or greater than the demand for formal publishing, which grows at $\pm 3 \%$ annually (Lin, 2018), it will look like a game of musical chairs where the number of children increases every time the music starts.

Contradictory pressures, poor service, and inadequate funding add up to an unattractive parlour game, so what's a researcher to do?

\section{Researchers adapt}

Like soldier ants working their way around obstacles, researchers, unimpressed by the conditioned and complicated access and sharing options offered by pay-wall publishers ${ }^{12}$, are discovering that there are easier ways to share and disseminate their data and results. It's no surprise to find that half of the non-OA articles posted to ResearchGate infringed copyright and/or publisher policies (Rumsey, 2018; Jamali,

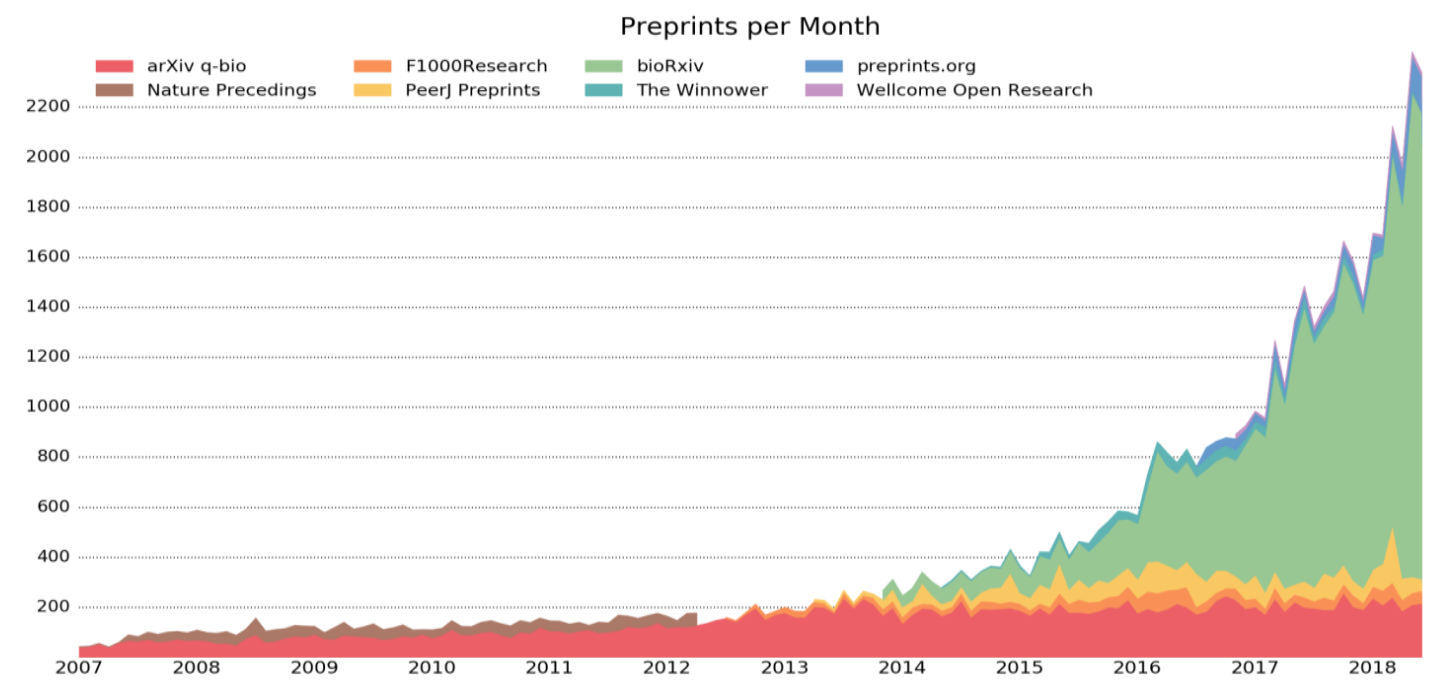

${ }^{12}$ Voluntary principles for article sharing on scholarly collaboration networks, revised $8^{\text {th }}$ June 2015 . https://www.stmassoc.org/2015_06_08_Voluntary_principles_for_article_sharing_on_scholarly_collaboration_networks.pdf

Figure 4: Preprints posted per month. Source: www.prepubmed.org 
Green, T: We're still failing to deliver $\mathrm{OA}$ and solve the serials crisis: to succeed we need a digital transformation of scholarly communication using internet-era principles.

2017) because hardly anyone reads terms and conditions (Obar \& Oeldorf-Hirsch, 2018). There's a growing appetite for informal publishing: Crossref has noticed a 30\% growth in preprints for the past two years powered by bioRxiv (figure 4) (Lin, 2018) and SSRN, Elsevier's recently acquired preprint platform, launched four new sections and is now being used to offer a preprint and preview service to Elsevier's prestige brands, The Lancet and $\mathrm{Cell}^{13}$. These alternative channels are friction free, fast and put the researcher in control. They are also effective, there is evidence that journals are losing citations to preprints (Davis, 2018) and traffic to repositories (Davis, 2013).

\section{A knotty problem, summarised}

Making scholarly communications OA is a knotty, multi-dimensional, problem. This is neatly illustrated by the case of more than 100 Finnish journals, today sustainably financed by a combination of subscriptions, membership fees and state subsidies. Whilst it may seem simple enough to flip the subscription income to fund author costs and keep the membership fees and subsidies going, making the journals open would probably undermine membership income since having access to pay-walled journals is a key membership benefit. The administration of APCs would introduce new costs and a 'playwall' for poorly-funded authors. The proposed solution, a national funding consortium, introduced new quandaries: quality standards, oversight, the degree to which journals retain their independence and the use of Finnish public money to fund non-Finnish authors. Most research universities, home to a majority of authors, were unwilling to contribute to the consortium because they would have had to find more money than they current spent on subscriptions (Ilva, 2018). What can cut this Gordian knot?

\section{OA paralysis}

As in the study of old constitutions, much effort is expended on interpreting what those drafting the ' $3 \mathrm{~B}$ ' OA declarations ${ }^{14}$ really meant. There could be 720 possible variants of OA for journal articles (MartínMartín et al, 2018b) and 91 different OA models are being tried for books ${ }^{15}$, so when does OA mean OA? Too much choice can paralyse (Schwartz, 2006) and the stagnation in the growth of OA suggests paralysis has indeed set in.

The signatories of the 3Bs foresaw three changes with the coming of the internet: that OA would lead to lower costs; to changes in the way scholarship is published; and in the way scholars are evaluated for appointments, promotion and grants. In today's jargon, they were imagining a 'digital transformation' of scholarly communications.

\footnotetext{
${ }^{13}$ SSRN Year-End Review 2017 http://ssrnblog.com/2017/12/22/ssrn-year-end-review-2017/

${ }^{14}$ Budapest http://www.budapestopenaccessinitiative.org/read , Bethesda https://legacy.earlham.edu/ peters/fos/bethesda.htm and Berlin https://openaccess.mpg.de/Berlin-Declaration

${ }^{15} \mathrm{http}$ ://oad.simmons.edu/oadwiki/OA_book_business_models
} 


\section{PREPRINT}

Green, T: We're still failing to deliver OA and solve the serials crisis: to succeed we need a digital transformation of scholarly communication using internet-era principles.

\section{Digital transformation}

Digital transformation is not just about technology, its about changing the way you work, about building a new type of organisation using internet-era principles. These changes are not complicated, they are just hard and often uncomfortable because it means changing both the back office and what is delivered to the user. Getting it right can deliver efficiency savings and improved services (Greenway et al, 2018).

The Gordian Knot described above makes it patently clear that scholcomms's efforts to deliver on the 3Bs, at digital transformation, have failed and that's because, rather than addressing them all together, we've been paralysed by just one of the three changes, OA.

Last year, I invited us all "tae think again" and learn from how the low-cost airlines unbundled their way to success (Green, 2017a). I have since learned that diverse groups promote more creativity, deeper thinking and encourage a greater range of viewpoints even if working with outsiders is uncomfortable and requires more effort (Gino, 2018). So, again, I think we should look outside scholcomm for lessons and learn from one part of the digital transformation of the UK's government services since 2011 - the mundane process of applying for a passport.

Previously, to renew my passport, as a UK citizen living outside the UK, I had to go to the British consulate, queue, collect and complete a long form, find documents in evidence and then ask a fellow citizen of good standing to 'peer-review' my application. It would have to be deposited in the consulate (more queuing), with photos, payment and, then a four-six week wait for the passport to arrive in the mail. Today, all I had to do was go to a website, complete a minimum amount of information, upload a photo, pay online, print out a single sheet of paper with a barcode, sign it, put it in an envelope with my old passport and send it by mail to the UK. The whole process took less than ten minutes and the new passport arrived in a week. Had my application been considered dodgy in any way, I'm sure it would have been routed for a more thorough process where documents would have been requested and the peer-review process used.

The key take-away here is that the process had been re-engineered from start to finish using internet-era principles - every part ruthlessly re-evaluated in my interest and in the interest of streamlining processes and reducing cost. Now compare that with scholcomm. Have we ruthlessly re-evaluated and re-engineered the scholcomm process around internet-era principles in the interests of its principle stakeholders, authors and readers, and to reduce cost?

\section{Failing fast, ruthlessly}

One of the internet-era principles is fail fast: you try something and if it fails, you stop and move on in another direction. What if authors posted papers onto preprint servers or repositories to test whether the paper 'succeeds' or 'fails'. If it fails, the author moves on in another direction. If it succeeds, only then the resource-heavy process of peer-review and formal publication would kick-in (see figure 5). 
Green, T: We're still failing to deliver $O A$ and solve the serials crisis: to succeed we need a digital transformation of scholarly communication using internet-era principles.

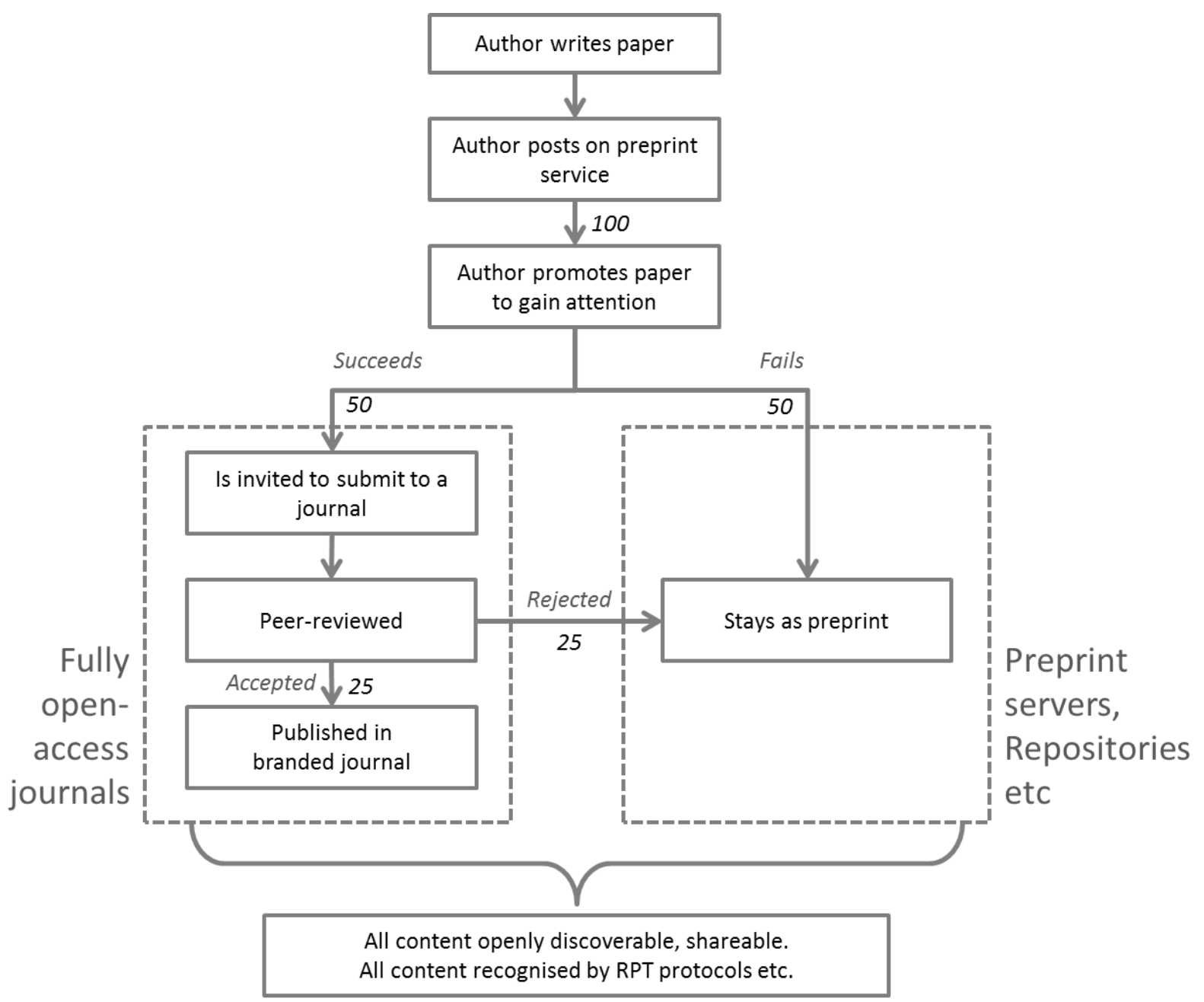

Figure 5: A digitally transformed 'fail-fast' workflow for publishing research findings

In the diagram, I have posited some numbers for the purpose of illustration: say $50 \%$ of papers succeed and of these, half survive peer-review, it follows that $25 \%$ of all papers are formally published.

The preprints are like my passport application - low cost and rapid. The formally published articles are like applications that need special attention and peer-review - a slower, costlier process. Crucially, the total cost in the system has fallen significantly because only $50 \%$ of all papers are peer-reviewed and just $25 \%$ incur the expense of formal publication. These numbers depend on the definition of 'success' but it's worth considering that $15 \%$ of recent papers remain uncited by anyone other than their authors (van Noorden, 2018), so did they warrant the full cost of peer-review and formal publication? A $15 \%$ saving on the USD25 billion cost of publishing is USD3.75 billion (Buranyi, 2017).

A process built on fail-fast principles would provide an incentive for authors to promote their papers so they do 'succeed', something funders and employers, concerned about the impact of their research dollars, might appreciate. 
Green, T: We're still failing to deliver $\mathrm{OA}$ and solve the serials crisis: to succeed we need a digital transformation of scholarly communication using internet-era principles.

Digital transformation means challenging past practices, incentives, behaviours and the unspoken rules of the game (Greenway et al, 2018) and it will be uncomfortable for some to accept a reformed workflow as proposed above, but without looking hard at the current process holistically, costs won't come down. If costs don't come down then I don't see how scholcomm can afford to publish on a sustainable basis, OA or otherwise.

\section{OA won't solve the serials crisis}

On reviewing the $3 \mathrm{Bs}$, I found it interesting that none specifically mentioned the serials crisis; there is an assumption that $\mathrm{OA}$ would reduce costs ${ }^{16}$ so I guess the serials crisis was in drafters' minds. A key driver behind the serials crisis was, and remains, the unsquareable arithmetic of an ever-growing volume of content outstripping the budgets available to pay for publishing research. Whether these budgets are used for subscriptions or APCs, an uncomfortable fact remains: the steady increase in scientific output (Anderson, 2013) needs to be matched by a steady increase in publishing capacity, and this costs money. If the money can't be found to pay for this increased capacity, then something has to change, structurally, about how scholarship is published: either the cost per article must come down or the number of articles published must be reduced.

There is no reason why OA, by itself, should reduce costs because costs can only fall if there is a remarkable efficiency or productivity improvement to the existing publishing process: switching business models doesn't reduce costs.

Today, all articles, whatever their quality or importance, are published using the same process. Ironically, papers that are of lower quality or importance attract higher processing costs because rejected authors are coached to revise and submit again (Laursen, 2008), the papers cascading down to lower-ranked journals. For example, Elsevier handles 1.5 million submissions a year (a figure that is growing $10 \%$ annually) of which 1.1 million articles are rejected (Fowler and Meijer, 2018) often for avoidable reasons like a mismatch with the journal's aims and scope (Editage Insights, 2013). Many submissions to Nature are declined without being sent for review ${ }^{17}$. Using the principles of digital transformation, is there a way to rethink the process to eliminate this unproductive use of time, effort and money?

\section{What if the submission process was flipped?}

Preprint services and repositories are much cheaper to run than journals. For example, the submission rate to arXiv is 12,000 per month ${ }^{18}$ and its annual budget is US $\$ 1.4 \mathrm{M}^{19}$; submissions to PLoS's fully OA journals ran at average of 5,000 a month in 2016 and expenses were US $\$ 39 \mathrm{M}^{20}$. That's an average 'upload' cost of USD9.70 for preprints versus USD650.00 for formal publication and, as we've seen, APCs are typically nearer the USD2,000 mark.

\footnotetext{
${ }^{16}$ At the time the 3Bs were drawn up, online publishing was still novel and the assumption was that costs could fall if printed editions were eliminated. The reality proved to be more complicated. (National Academy of Sciences, 2004).

${ }^{17} \mathrm{https} / / / \mathrm{www}$.nature.com/nature/for-authors/editorial-criteria-and-processes

${ }_{18} \mathrm{https}: / /$ arxiv.org/stats/monthly_submissions

19 https://confluence.cornell.edu/display/arxivpub/arXiv+Budgets+and+Reserve+Fund+Policy

${ }^{20} \mathrm{https://www.plos.org/financial-overview}$
} 
Green, T: We're still failing to deliver $\mathrm{OA}$ and solve the serials crisis: to succeed we need a digital transformation of scholarly communication using internet-era principles.

Introducing submission fees could provide an incentive for authors to submit responsibly (Ware, 2010) but what if the submission process was flipped so that journal editors invited submission from authors of interesting pre-prints? If Elsevier's figures are typical for all publishers, millions fewer submissions would need to be handled, reducing the cost of upstream submission processes by perhaps half or more.

The key catalyst for such a change is for the reputation economy to recognise preprints. If preprints were accepted into the reputation economy then the appetite for authors to be published in journals would fall and journals could either shrink, merge with others or close, stripping out more costs. If the reputation economy accepted preprints, predatory publishers might struggle to find a market.

\section{Preprints make science better}

Despite authors wanting a rapid publishing process (Mabe and Mulligan, 2011), the formal, peer-review, publication process is still on 'analogue-era' time, leading to complaints (Farris, 2018; Bal, 2018). Contrast that with publishing on preprint servers - an internet-era process that takes minutes (unmoderated) or a day or two (moderated). More substantively, Stephen Curry, Chair of DORA's Steering Committee, argues:

"Preprints make science better because they speed up the rate at which new results can be absorbed, critiqued and built on. The fact that preprints are 'unbranded' helps to refocus attention where it should be - not on the name of the journal where it is eventually published, but on its contents ${ }^{21}$ ".

Preprints are becoming mainstream (Luther, 2017). Long part of the publishing ecosystem in some fields (e.g. high-energy physics with arXiv, and economics with Repec) the burgeoning of "rXivs' ${ }^{22}$ and the purchase of SSRN by Elsevier show that preprints are rapidly becoming acceptable in other fields too. Preprints with DOIs are popping up in discovery services and pathways between preprints and final papers are appearing in channels such as Nature, PlosOne and Plant Direct Journal.

Encouragingly, there are already moves to look beyond journals when assessing researchers: the UK's REF will accept submissions of 'near final' versions to arXiv and, the EU's Horizon Europe funding programme is expected to accept that preprints will satisfy the EU's OA requirements in 2019 (Curry, 2018; Kingsley, 2018b; European Research Council, 2018).

\section{Coping with fake science is no different to coping with fake news}

As in any digital transformation, the changes will be uncomfortable and the rise of preprints has prompted debate: journalists could 'scoop' their rivals with stories from non-peer-reviewed papers; and audiences, especially non-specialists, could be mis-lead or confused by work that is subsequently changed, or even withdrawn, once it hits the peer-review process (Sheldon, 2018; Moody, 2018). Yet the peer-review process, while valued by scholars (Rowley \& Sbaffi, 2007) and held up as the guarantor of quality, is not

\footnotetext{
${ }^{21} \mathrm{https}: / /$ wesupportpreprints.wordpress.com/2018/08/27/stephen-curry/

22 For example, fifteen 'rXivs' are hosted on the OSF open source infrastructure https://osf.io/preprints/
} 
Green, T: We're still failing to deliver $\mathrm{OA}$ and solve the serials crisis: to succeed we need a digital transformation of scholarly communication using internet-era principles.

fail-safe since retractions can include Nobel laureate laboratories and top journals ${ }^{23}$ and there is talk of a replication 'crisis' in the social sciences (Bower, 2018).

An omelette can't be unmade: as we've seen, researchers are readily sharing their findings through informal channels and this won't stop. Journalists, researchers and the public will have to adapt to the internet era in understanding, debating and sharing research findings just as in other areas of public information and debate: coping with fake science is no different to coping with fake news.

\section{Fail fast experiments}

Unbundling the publishing process into 'fail-fast' stages is being tested by the University of North Carolina Press. They are flipping the traditional history monograph model (print first, digital later) so that a simple, digital, edition is released first and only if the work achieves 'success' does the more expensive, fullydesigned, print and e-book edition appear. This digital transformation is more likely succeed because it involves changing attitudes so that the simple, digital, version is acceptable to the monograph reputation economy of vendors, reviewers and award juries (Sherer, 2018).

At OECD Publishing, we are testing a process where we release a simple, digital, version within four days of acceptance, tagged as a 'version for rapid dissemination' (VRD) so readers know it is not yet a version of record (VoR). If the work gains attention, then we'll invest in increased reader functionality to create a full range of e- and print editions and replace the VRD with the VoR. The pause to see if the work gains attention will allow the author time to make last-minute corrections or updates (something that is more and more in demand). If the work doesn't gain attention, and the author is satisfied that no more corrections or updates are forthcoming, we'll re-tag the VRD as a VoR.

\section{Conclusion}

In screening out works of poor quality, traditional publishing was in the service of the reader (Esposito, 2008) prompting this musing, attributed to Goethe: "publishers are all cohorts of the devil: there must be a special hell for them somewhere." One can argue the point about how good publishers were at screening, but traditional scholarly publishers were the providers of a limited resource, namely sustainable dissemination channels (i.e. journals) for authors to find readers and these became a central part of the 'publish or perish' ${ }^{24}$ reputation ecosystem. These channels only ever found a sub-set of readers, the haves, an inequality which the internet and paywalls made all too visible to the have-nots.

The internet has lowered the cost of running dissemination channels to the point where, potentially, the haves can include everyone with an internet connection but scholcomm, in clinging to its reputation ecosystem is, unintentionally, supporting the old pay-walled dissemination channels and thus slowing

\footnotetext{
${ }^{23}$ https://retractionwatch.com/category/by-journal/science-journal-retractions/ The Retraction Watch website reports that there are some 500-600 retractions a year, a tiny fraction of the ca.2.5 million papers publishing annually. I could not find any data on the number of preprints retracted.

${ }^{24}$ https://en.wikipedia.org/wiki/Publish_or_perish
} 
Green, T: We're still failing to deliver $\mathrm{OA}$ and solve the serials crisis: to succeed we need a digital transformation of scholarly communication using internet-era principles.

migration to fully OA channels. In clinging onto the traditional channels to advance the careers of the few (authors), OA is delayed for the many (readers).

But the free flow of information must be for authors too. Where the traditional publishing model put up a financial barrier for readers the danger of APCs is that the financial barrier is flipped and only those with access to means will be able to share their research, opening the door to the perils of patronage. It is all very well for Plan S to acknowledge that "all scientists should be able to publish their work OA even if their institutions have limited means", the challenge is to find a sustainable way to make it happen. Equally, regional approaches to OA risk splintering an activity that is increasingly global (Green, 2017b): a solution that can work across regions and disciplines is needed. Creating a market for APCs changes incentives for publishers that may undermine quality standards.

OA, on its own, cannot solve the serials crisis driven as it is by the unsquareable arithmetic of an evergrowing volume of content outstripping the budgets available to pay for publishing it. If new funds can't be found and research budgets are not to be tapped, the only solution is a radical re-think of the publishing process to cut the average cost of publishing a paper.

Behavioural scientists know that to change individual behaviour you need to change the reward system (Lawson \& Price, 2003), so the criteria for assessing funding decisions and career advancement must be changed if authors are to consider alternatives to the pay-wall 'reputation economy' journals. Until then, author support for OA will be less than wholehearted.

It's well known that most journal publishers, both commercial and society, generate significant profit margins so it is tempting to imagine that if prices could be managed down in some way, the crisis would ease and OA afforded. But attempts at price control in the form of price caps won't work because price controls never do (Scott Morton, 2001). Calls for greater transparency and attempts to manage costs through 'standardised' prices will be no more successful than Henry Ford's attempt to stick with a standard model $\mathrm{car}^{25}$.

Preprint services and repositories are much cheaper to run than journals with the cost per article published being around 100 times cheaper. If, using the internet-era principle of 'fail-fast', all articles were first published as preprints and only those that succeeded in attracting the attention of journal editors were invited to be put forward for formal publishing, the average cost of publishing a paper would fall significantly. The catalyst for this change would be for the reputation economy to accept preprints in the same way as 'cascaded' articles in journals today.

As the signatories of the 3Bs understood, all aspects of scholcomm have to be re-thought if the Gordian Knot is to be cut: a digital transformation of scholcomm is needed. Digital transformation is about changing whole systems using internet-era principles and whilst easy to do, it is uncomfortable for incumbents. It is not just about using better technology or flipping business models, it is about changing the way a service is delivered and the ecosystem that surrounds it, in the interest of the user, and iteratively

\footnotetext{
${ }^{25}$ Ford's stubborn refusal to move on from offering a single, standard, model to match General Motor's marketing-led, diversified,
} product line severely damaged his company and led to GM becoming market leader in the 1930s (O'Brien, 1989). 
Green, T: We're still failing to deliver OA and solve the serials crisis: to succeed we need a digital transformation of scholarly communication using internet-era principles.

improving it over and again. Until scholcomm embraces digital transformation, the pirates and predators will keep winning the OA race and the serials crisis won't go away.

\section{Author's Note}

In keeping with the proposition in this paper, and following the advice of Pippa Smart, Editor of Learned Publishing who saw an early draft, I'm releasing it first as a preprint to test if it 'fails fast' or not. I will do my best to promote it so that it gains an audience and I invite readers to comment, propose improvements and point out where I've gone wrong. I also invite journal editors to consider whether it has 'succeeded' and if in their opinion it has I look forward to being asked to submit it for peer review and formal publication in due course.

\section{References}

Alperin, J-P. (2018) The number and proportion of freely available articles is growing; reaching $45 \%$ of the literature published in 2015. LSE The Impact Blog.

http://blogs.lse.ac.uk/impactofsocialsciences/2017/08/07/the-number-and-proportion-of-freely-availablearticles-is-growing-reaching-45-of-the-literature-published-in-2015/

Alperin, J-P., Niles, M., McKiernan, E., Schimanski, L., Muñoz Nieves, C., (2018) Preliminary Findings from the Review, Promotion, and Tenure Study, Scholcommlab Blog 30 ${ }^{\text {th }}$ May 2018

https://www.scholcommlab.ca/2018/05/30/preliminary-findings-from-the-review-promotion-and-tenurestudy/

Anderson, K. (2013) Have journal price increases really increased much in the digital age? Scholarly Kitchen Blog, $8^{\text {th }}$ January 2013 https://scholarlykitchen.sspnet.org/2013/01/08/have-journal-prices-reallyincreased-in-the-digital-age/

Anderson, K. (2018a) The New Plugins - What Goals Are the Access Solutions Pursuing? Scholarly Kitchen Blog https://scholarlykitchen.sspnet.org/2018/08/23/new-plugins-kopernio-unpaywall-pursuing/

Anderson, K., (2018b) Dropping the hammer: predatory publishers get pounded by regulators and the press. Scholarly Kitchen Blog. $30^{\text {th }}$ July 2018. https://scholarlykitchen.sspnet.org/2018/07/30/droppinghammer-predatory-publishers-get-pounded-regulators-press/

Anderson, K. (2018c) “Open," Patronage, and Proposition S, Caldera Publishing Blog $5^{\text {th }}$ September 2018 http://www.caldera-publishing.com/blog/2018/9/5/open-patronage-and-proposition-s

Anderson, R., (2018a) When the Wolf Finally Arrives: Big Deal Cancellations in North American Libraries. Scholarly Kitchen Blog. $5^{\text {th }}$ May 2018, https://scholarlykitchen.sspnet.org/2017/05/01/wolffinally-arrives-big-deal-cancelations-north-american-libraries/ 


\section{PREPRINT}

Green, $\mathrm{T}$ : We're still failing to deliver $\mathrm{OA}$ and solve the serials crisis: to succeed we need a digital transformation of scholarly communication using internet-era principles.

Anderson, R., (2018b). Denialism on the rocks: It just got a lot harder to pretend that predatory publishing doesn't matter. Scholarly Kitchen Blog $7^{\text {th }}$ August 2018, https://scholarlykitchen.sspnet.org/2018/08/07/denialism-rocks-just-got-lot-harder-pretend-predatorypublishing-doesnt-matter/

Bal, M (2018) Let's abolish the peer-review system media theory $3^{\text {rd }}$ September 2018 http://mediatheoryjournal.org/mieke-bal-lets-abolish-the-peer-review-system/

Beall, J., (2017) What I learned from predatory journals. Biochemia Medica 27(2) 273-278 https://doi.org/10.11613/BM.2017.029

Boukacem-Zegmouri, C., Dillaerts, H., Lafouge, T., Bador, P., Sauer-Avargues, A. (2018) French publishing attitudes in the open access era: The case of mathematics, biology, and computer science. Learned Publishing $4^{\text {th }}$ July 2018 https://doi.org/10.1002/leap.1169

Bosman, J and Kramer, B (2018), Open Access levels: a quantitative exploration using Web of Science and oaDOI data. PeerJ Preprint. https://doi.org/10.7287/peerj.preprints.3520v1

Bower, B., (2018) 'Replication crisis' spurs reforms in how science studies are done. ScienceNews $27^{\text {th }}$ August, 2018 https://www.sciencenews.org/blog/science-public/replication-crisis-psychology-sciencestudies-statistics

Boyes, P. and Kingsley, D. (2016) Hybrid open access - an analysis. Unlocking Research Blog. October $24^{\text {th }}$ 2016. https://unlockingresearch-blog.lib.cam.ac.uk/?p=969

Buranyi, S., (2017) Is the staggeringly profitable business of scientific publishing bad for science? The Guardian The Long Read, 27 June 2017. https://www.theguardian.com/science/2017/jun/27/profitablebusiness-scientific-publishing-bad-for-science

Caldeira, K (2018). Tweet "My institution considers purchases over $\$ 5000$ to be a capital expense ..." Twitter 16" August 2018 @ KenCaldeira

Chan, G., (2018) Scholarly communication at the crossroad: from subscription to open access? Paper presented at IFLA WLIC 2018, submitted on $15^{\text {th }}$ June 2018. http://library.ifla.org/2192/1/163-chan-en.pdf

Curry, S., (2018) Let's move beyond the rhetoric: it's time to change how we judge research. Nature News $7^{\text {th }}$ February 2018. https://www.nature.com/articles/d41586-018-01642-w Davis, P. (2018) Journals Lose Citations to Preprint Servers. Scholarly Kitchen Blog 21st May 2018 https://scholarlykitchen.sspnet.org/2018/05/21/journals-lose-citations-preprint-servers-repositories/ Davis, P. (2013) Public Accessibility of Biomedical Articles from PubMed Central reduces journal readership - retrospective cohort analysis. FASEB Journal Vol 27 No 7 (2013) https://doi.org/10.1096/fj.13-229922 


\section{PREPRINT}

Green, $\mathrm{T}$ : We're still failing to deliver $\mathrm{OA}$ and solve the serials crisis: to succeed we need a digital transformation of scholarly communication using internet-era principles.

Davis, P. (2018) Journals lose citations to preprints servers Scholarly Kitchen Blog $21^{\text {st }}$ May 2018 https://scholarlykitchen.sspnet.org/2018/05/21/journals-lose-citations-preprint-servers-repositories/

DORA (2012) San Francisco declaration on research assessment. https://sfdora.org/read/

Economist, The (2018) Publish and don't be damned: Some science journals that claim to peer review papers do not do so. The Economist $23^{\text {rd }}$ June 2018. https://www.economist.com/science-andtechnology/2018/06/23/some-science-journals-that-claim-to-peer-review-papers-do-not-do-so

Editage Insights (2013) Most common reasons for journal rejection. 12 ${ }^{\text {th }}$ November 2013. https://www.editage.com/insights/most-common-reasons-for-journal-rejection

Else, H. (2018) Radical open-access plan could spell end to journal subscriptions. Nature News $4^{\text {th }}$ September 2018 https://www.nature.com/articles/d41586-018-06178-7

Esposito, J., (2018a) Libraries face a future of open access. Scholarly Kitchen Blog $23^{\text {rd }}$ May 2018 https://scholarlykitchen.sspnet.org/2018/05/23/libraries-face-future-open-access/

Esposito, J., (2018b) Counting the holes in the Swiss cheese: "Read and publish" discovers America. Scholarly Kitchen Blog $20^{\text {th }}$ June 2018. https://scholarlykitchen.sspnet.org/2018/06/20/counting-holesswiss-cheese-read-publish-discovers-america/

Esposito, J., (2008) Open access 2.0: Access to scholarly publications moves to a new phase. Journal of Electronic Publishing 11 (2) https://dx.doi.org/10.3998/3336451.0011.203

European Research Council (2018) Main Changes Expected in the ERC Work Programme 2019 (PowerPoint Presentation) https://erc.europa.eu/sites/default/files/content/pages/pdf/ERC-2019-WorkProgramme-main-changes.pdf

Eve, M. P., (2018) Transparency agendas are being used to legisltate against consortial open-access models even though it has good cost outcomes. Martin Paul Eve Blog. $3^{\text {rd }}$ June 2018 https://www.martineve.com/2018/06/03/transparency-agendas-are-used-to-legislate-against-consortialopen-access-models/

Farris, E (2018). Tweet: “Just got a second paper rejected after months because editors couldn't get reviewers to review in a timely manner ..."Twitter 6 ${ }^{\text {th }}$ August, 2018. @emayfarris

Fowler, N. and Meijer, G., (2018) What's the big DEAL and why is it so difficult to reach? Elephant in the Lab https://doi.org/10.5281/zenodo.1404031

Green, T., (2017a) We've failed: Pirate black open access is trumping green and gold and we must change our approach. Learned Publishing 2017; 30(4), 325-329 https://doi.org/10.1002/leap.1116 


\section{PREPRINT}

Green, $\mathrm{T}$ : We're still failing to deliver $\mathrm{OA}$ and solve the serials crisis: to succeed we need a digital transformation of scholarly communication using internet-era principles.

Green, T., (2017b) A response to Elsevier's insights into making the transition to open access possible. Medium $27^{\text {th }}$ September 2017 https://medium.com/ @ TobyABGreen/a-response-to-elseviers-insights-intomaking-the-transition-to-open-access-possible-f3deb155b061

Greenway, A., Terret, B., Bracken, M., Loosemore, T. (2018) Digital transformation at scale: why the strategy is delivery. London Publishing Partnership. ISBN 978-1907994784. http://londonpublishingpartnership.co.uk/digital-transformation-at-scale/

Gino, F., (2018). Rebel Talent: Why it pays to break the rules at work and in life. Dey Street Books (New York). ISBN: 978-0-06-269463-8

Heinemann, E., et al (2018) OPERAS Advocacy White Paper, OPERAS Open Access in the European Research Area through Scholarly Communication. Zenodo. 30 ${ }^{\text {th }}$ July 2018 http://doi.org/10.5281/zenodo.1324036

Hern, A., and Duncan, P. (2018) Predatory publishers: the journals that churn out fake science. The Guardian $10^{\text {th }}$ August 2018. https://www.theguardian.com/technology/2018/aug/10/predatory-publishersthe-journals-who-churn-out-fake-science

Hersh, G. (2017) Working towards a transition to open access. Elsevier Connect 26th September 2017 https://www.elsevier.com/connect/working-towards-a-transition-to-open-access

Himmelstein, D. S., et al. (2018). Research: Sci-Hub provides access to nearly all scholarly literature. eLife. 2018;7:e32822 https://doi.org/10.7554/eLife.32822.001

Hinchliffe, L (2018). Tweet: "I especially worry re locking in with APC big deals to replace subscription Big Deals. Inequity in who can afford to publish and allocates all the $\$$ to already dominant platforms/publishers". Twitter 19th June 2018 @ lisalibrarian

Horton, R (2018) Tweet: "The APC model is incentivising some publishers to set ambitious goals for number of published papers. Quality is not part of (the) equation." Twitter $5^{\text {th }}$ September 2018 @ richardhorton1

Ibero-American and Caribbean Consortium (2017): Declarations, First Consortium Assembly from IberoAmerica and the Caribbean, $1^{\text {st }}$ September 2017: http://reuniondeconsorcios.conricyt.mx/index.php/primers-reunion/declaraciones/?lang=en

Ilva, J. (2018). Looking for commitment: Finnish open access journals infrastructure and funding. Insights 31, 25 http://doi.org/10.1629/UKSG.414

Jamali, H. R., (2017) Copyright compliance and infringement in ResearchGate full-text journal articles. Scientometrics, 112(1), 241-254. https://doi.org/10.1007/s11192-017-2291-4 
Green, T: We're still failing to deliver $\mathrm{OA}$ and solve the serials crisis: to succeed we need a digital transformation of scholarly communication using internet-era principles.

Johnson, A., Mika, K., Cantrell, M., Caillet, R., (2018) State of open at the University of Colorado Boulder: a baseline analysis of open access practices from 2012-2018. University Libraries, University of Colorado Boulder. Https://doi.org/10.25810/VPRN-V113

Johnson, R. (2018) Time to check out of the hybrid hotel? Scholarly Kitchen Blog Guest Post $25^{\text {th }}$ June 2018. https://scholarlykitchen.sspnet.org/2018/06/25/guest-post-time-check-hybrid-hotel/?informz=1

Kamerlin, L. (2018) Tweet "I cannot see a good outcome from banning EU researchers from publishing in JACS” Twitter $5^{\text {th }}$ September $2018 @$ kamerlinlab

Kämper, B-C., (2018) email reply to Liblicense-L posting "German and Swedish libraries shrug off Elsevier shutdown" $12^{\text {th }}$ August 2018. http://listserv.crl.edu/wa.exe?A2=ind1808\&L=LIBLICENSE$\underline{L \& P}=28485$

Kingsley, D., (2018a) Compliance is not the whole story. Unlocking Research Blog. $14^{\text {th }}$ June 2018 https://unlockingresearch-blog.lib.cam.ac.uk/?p=2074

Kingsley, D., (2018b) Tweet: "At Last: submissions to arXiv will be counted for REF if 'near final' version is on preprint server before publication.” Twitter 23 ${ }^{\text {rd }}$ July 2017 @ dannykay68

Kingsley, D. and Boyes, P. (2016) Who is paying for hybrid? Unlocking Research Blog. October $24^{\text {th }}$ 2016. https://unlockingresearch-blog.lib.cam.ac.uk/?p=1002

Kurt, K., (2018). Why do authors publish in predatory journals. Learned Publishing 31(2) 141-147. https://doi.org/10.1002/leap.1150

Laursen, L. (2008) If at first you don't succeed, cool off, revise, and submit again. Science Magazine $15^{\text {th }}$ August 2008. http://www.sciencemag.org/careers/2008/08/if-first-you-dont-succeed-cool-revise-andsubmit-again

Lawson, E. and Price, C., (2003) The psychology of change management. McKinsey Quarterly June 2003. https://www.mckinsey.com/business-functions/organization/our-insights/the-psychology-of-changemanagement

Lin, J. (2018) Preprints growth rate ten times higher than journal articles. CrossRef Blog. $31^{\text {st }}$ May 2018 https://www.crossref.org/blog/preprints-growth-rate-ten-times-higher-than-journal-articles/

Liu, W. and Li, Y. (2017) Open access publications in sciences and social sciences: a comparative analysis. Learned Publishing 31: 107-119 https://doi.org/10.1002/leap.1114

Luther, J., (2017) The stars are aligning for preprints. Scholarly Kitchen Blog $18^{\text {th }}$ April 2017. https://scholarlykitchen.sspnet.org/2017/04/18/stars-aligning-preprints 


\section{PREPRINT}

Green, $\mathrm{T}$ : We're still failing to deliver $\mathrm{OA}$ and solve the serials crisis: to succeed we need a digital transformation of scholarly communication using internet-era principles.

Mabe, M. and Mulligan, A., (2011) What Journal Authors Want: Ten Years of Results from Elsevier's Author Feedback Programme, New Review of Information Networking, 16:1, 71-89, https://doi.org/10.1080/13614576.2011.574495

Martin, S. (2018) Social Problems of Scholarly Communication. History of Scholarly Communication Blog $25^{\text {th }}$ June 2018. https://histscholcomm.wordpress.com/2018/06/25/social-problems-of-scholarlycommunication/

Martín-Martín, A., Costas, R., van Leeuwen, T., López-Cózar, E., (2018a) Evidence of Open Access of scientific publications in Google Scholar: A large-scale analysis. Journal of Informetrics 12 (3) 819-841 https://doi.org/10.1016/j.joi.2018.06.012

Martín-Martín, A., Costas, R., van Leeuwen, T., López-Cózar, E., (2018b) Unbundling open access dimensions: A conceptual discussion to reduce terminology inconsistencies. arXiv. $13^{\text {th }}$ June 2018. https://arxiv.org/abs/1806.05029

Matthias, L. (2018) The worst of both worlds: hybrid open access. OpenAire Blog. 26 Jun 2018 https://blogs.openaire.eu/?p=3431

Moody, G. (2018) As academic publishers fight and subvert open access, preprints offer an alternative approach for sharing knowledge widely. Techdirt. $17^{\text {th }}$ August 2018.

https://www.techdirt.com/articles/20180816/06022140441/as-academic-publishers-fight-subvert-openaccess-preprints-offer-alternative-approach-sharing-knowledge-widely.shtml

National Academy of Sciences (2004). Electronic scientific, technical, and medical journal publishing and its implications: report of a symposium ISBN: 978-0-309-09161-9 https://doi.org/10.17226/10969

National Library of Sweden (2018). Alternative routes to scholarly articles and research outputs OpenAccess.se website. http://openaccess.blogg.kb.se/bibsamkonsortiet/alternative-routes-to-scholarlyarticles-and-research-outputs/

Neuerburg, L. (2018) Sunsetting of the Open Access Fund. University of Iowa Libraries Blog $12^{\text {th }}$ July 2018. https://blog.lib.uiowa.edu/science/2018/07/12/sunsetting-of-the-oa-fund/

O'Brian, A.P. (1989) How to succeed in business: lessons from the struggle between Ford and General Motors during the 1920s and 1930s. Business and Economic History, Second Series, Volume 18, 79-87, 1989. http://www.thebhc.org/sites/default/files/beh/BEHprint/v018/p0079-p0087.pdf

Obar, J. A., and Oeldorf-Hirsch, A. (2018) The biggest lie on the internet: ignoring the privacy policies and terms of service policies of social networking services. TPRC 44: The $44^{\text {th }}$ Research Conference on Communication, Information and Internet Policy 2016. SSRN https://dx.doi.org/10.2139/ssrn.2757465 


\section{PREPRINT}

Green, T: We're still failing to deliver OA and solve the serials crisis: to succeed we need a digital transformation of scholarly communication using internet-era principles.

Oberhaus, D. (2018) Hundreds of researchers from Harvard, Yale and Stanford were published in fake academic journals. Motherboard. $14^{\text {th }}$ August 2018.

https://motherboard.vice.com/en_us/article/3ky45y/hundreds-of-researchers-from-harvard-yale-andstanford-were-published-in-fake-academic-journals

Peterson, A.T. et al (2018) Diversity and Distributions protest letter, $22^{\text {nd }}$ August 2018, https://plus.google.com/101228061637329814897/posts/cv77LBrjsEJ

Pinhasi, R., Blechl, G., Kromp, B., \& Schubert, B. (2018). The weakest link - workflows in open access agreements: the experience of Vienna University Library and recommendations for future negotiations. Case study. Insights. 31, 27. http://DOI.org/10.1629/uksg.419

Pinfield S., and Johnson R., (2018) Adoption of open access is rising - but so too are its costs. LSE Impact of Social Sciences Blog Jan 22, 2018. http://blogs.lse.ac.uk/impactofsocialsciences/2018/01/22/adoptionof-open-access-is-rising-but-so-too-are-its-costs/

Piwowar et al. (2018), The State of OA: A large scale analysis of the prevalence and impact of Open Access articles. PeerJ 6:e4375; https://doi.org/10.7717/peerj.4375

Poynder, R., (2018a) OA big deals: VSNU embraces greater transparency. Open and Shut Blog. $9^{\text {th }}$ July 2018, https://poynder.blogspot.com/2018/07/oa-big-deals-vsnu-embraces-greater.html

Poynder, R., (2018b) Preface: Open Divide? Open and Shut Blog. 2nd January 2018, https://poynder.blogspot.com/2018/01/preface-open-divide.html

Poynder, R., (2018c) Six questions about openness in science: Green OA. Open and Shut Blog. $14^{\text {th }}$ May 2018 https://poynder.blogspot.com/2018/05/six-questions-about-openness-in-science.html\#more

Priyadarshini, S., (2018) India targets universities in predatory-journal crackdown. Nature News $28^{\text {th }}$ August 2018 https://www.nature.com/articles/d41586-018-06048-2

Pyne, D., (2017) The rewards of predatory publications at a small business school. Journal of Scholarly Publishing 48 (3) 137-160. https://doi.org/10.3138/jsp.48.3.137

Raju, R., (2018) From green to gold to diamond: open access's return to social justice. Paper presented at IFLA WLIC 2018, submitted $23^{\text {rd }}$ July 2018 http://library.ifla.org/2220/1/092-raju-en.pdf

Rowley, J. and Sbaffi, L. (2017) Academics' attitudes toward peer review in scholarly journals and the effect of role and discipline Journal of Information Science $14^{\text {th }}$ November 2017 https://doi.org/10.1177/0165551517740821

Rumsey, S., (2018) Discussion Paper: Help! I'm an author - get me out of here. University of Oxford, $24^{\text {th }}$ July 2018. https://ora.ox.ac.uk/objects/pubs:890971 


\section{PREPRINT}

Green, T: We're still failing to deliver OA and solve the serials crisis: to succeed we need a digital transformation of scholarly communication using internet-era principles.

Schimmer, R., Geschuhn, K.K., Vogler, A. (2015) Disrupting the subscription journals' business model for the necessary large-scale transformation to open access. A Max Planck Digital Library Open Access Policy White Paper. https://dx.doi.org/10.17617/1.3

Schonfeld, R., (2018a) Read and publish: is it good for the academy? Scholarly Kitchen Blog $4^{\text {th }}$ September 2018. https://scholarlykitchen.sspnet.org/2018/09/04/read-publish-good-academy/

Schonfeld, R., (2018b) Will Europe lead a global flop to open access. Scholarly Kitchen Blog $26^{\text {th }}$ June 2018. https://scholarlykitchen.sspnet.org/2018/06/26/will-europe-lead-open-access/

Schwartz, B., (2006): Choice isn't always better. Harvard Business Review June 2006 https://hbr.org/2006/06/more-isnt-always-better

ScienceEurope (2018). Challenging the current business models in academic publishing: accelerators and obstacles to the open access transition. Workshop report. June 2018. https://www.scienceeurope.org/wpcontent/uploads/2018/06/SE WS Report OA Big Deals.pdf

Scott Morton, F., (2001). The problems of price controls. Cato Institute. https://www.cato.org/publications/commentary/problems-price-controls

Shen, C. and Björk, B-C. (2015) 'Predatory' open access: a longitudinal study of article volumes and market characteristics. BMC Medicine 2015 13:230 https://doi.org/10.1186/s12916-015-0469-2

Sheldon, T. (2018) Preprints could promote confusion and distortion. Nature News. $25^{\text {th }}$ July 2018. https://www.nature.com/articles/d41586-018-05789-4

Sherer, J., (2018) Open access history monograph initiative. Longleaf Services Blog. $13^{\text {th }}$ June 2018. http://www.longleafservices.org/blog/oa-monographs/

Simba Information (2018) Open Access Sales Exceed Expectations, press release about the Simba Information Report Open Access Publishing 2018-2022. 15 ${ }^{\text {th }}$ July 2018.

https://www.simbainformation.com/about/release.asp?id=4369

Smith, C. (2018) Q\&A about the cancellation of the agreement with Elsevier commencing 1 July. OpenAccess.se Blog. 20 June 2018. http://OpenAccess.blogg.kb.se/2018/06/20qa-about-the-cancellationof-the-agreement-with-Elsevier-commencing-1-July/

SpringerNature (2018), Assessing the open access effect for hybrid journals. June 2018 https://www.springernature.com/gp/open-research/about/oa-effect-hybrid 


\section{PREPRINT}

Green, T: We're still failing to deliver OA and solve the serials crisis: to succeed we need a digital transformation of scholarly communication using internet-era principles.

Stockholm University (2018) Library press release $29^{\text {th }}$ June 2018. https://www.su.se/english/library/aboutus/press-information/2.42247/stockholm-university-gives-researchers-more-support-to-get-published-infull-open-access-journals-1.392523

Suber, P., (2017) Still true: 70\% of peer-reviewed OA journals charge no APCs. Google+ Post $26^{\text {th }}$ October 2017 https://plus.google.com/+PeterSuber/posts/aaAknRyN9cs

Times Higher Education (2018), German and Swedish libraries shrug off Elsevier shutdown. $7^{\text {th }}$ August 2018. https://www.timeshighereducation.com/news/german-and-swedish-libraries-shrug-elseviershutdown

Universities UK. (2017) Monitoring the Transition to Open Access. Report. https://www.universitiesuk.ac.uk/policy-and-analysis/reports/Documents/2017/monitoring-transition-openaccess-2017.pdf

University of California (2018). University Committee on Library and Scholarly Communication. Declaration of Rights and Principles to Transform Scholarly Communication. 25 April 2018 https://senate.universityofcalifornia.edu/_files/committees/ucolasc/scholcommprinciples-20180425.pdf

van der Graaf, M., (2017) Paying for open access: the author's perspective. Zenodo. http://doi.org/10.5281/zenodo.438037

van Noorden, R., (2018) Science journals end open-access trial with Gates Foundation. Nature News. 13 July 2018. Http://www.nature.com/articles/d41586-018-05729-2

van Otegem, M; Wennstrom, S; and Hormia-Poutanen, K. (2018) Five principles to navigate a bumpy golden road towards open access. Insights 31, 16 DOI: http://DOI.org/10.1629/UKSG.403

Ware, M. (2010) Submission fees - a tool in the transition to open access? Knowledge Exchange March 2010 http://repository.jisc.ac.uk/6473/1/Submission_Fees_-

_A_Tool_in_the_Transition_to_Open_Access.pdf

Worlock, D. (2018) After the IPO was over ... DavidWorlock.com Blog, $11^{\text {th }}$ May 2018. http://www.davidworlock.com/2018/05/after-the-ipo-was-over-a/ 